\begin{tabular}{|c|c|}
\hline $\begin{array}{l}\text { MINING AND METALLURGY INSTITUTE BOR } \\
\text { UDK: } 622\end{array}$ & $\begin{array}{l}\text { ISSN: 2334-8836 (Štampano izdanje) } \\
\text { ISSN: 2406-1395 (Online) }\end{array}$ \\
\hline UDK: $622.271: 504.06(045)=111$ & doi:10.5937/mmeb1704165M \\
\hline
\end{tabular}

\title{
THE IMPACT OF BLASTING ON THE ENVIRONMENT IN THE OPEN PIT MINING***
}

\begin{abstract}
In the open pit mining of mineral raw materials, blasting, whose role is to break the undisturbed mass for easier loading, is the necessary technological phase. In the mass blasting at the open pits of metal ore, there is a rise of cloud composed of gases and dust, blasting mining products, which have negative effects on the surrounding environment. This work presents the calculations of a cloud size, concentration of gases and dust in blasting.

Keywords:
\end{abstract}

\section{INTRODUCTION}

Development of a modern society is based on the need to fill the demand for goods and services, so the industry has to evolve and adapt, to be able to secure and market these products (Kogel et al., 2006). The first step in this process is the supply of raw materials for further processing and transformation. In fact, mining could become one of the major forces in the global economy, which takes a vital position in the supply chain of raw materials (Jorge Castilla-Gómez, et al, 2015). In this scenario, mining is facing one of the biggest challenges that can arise in any industrial activity. It is the exploitation of mineral raw materials from the Earth's crust, and in doing so, no negative effects on the environment are created. Since this is hardly feasible in practice, certain protective measures that reduce

the effects or completely neutralize them, are applied in mining.

\section{EXPLOITATION OF MINERAL \\ RAW MATERIALS AND \\ POTENTIAL EFFECT ON \\ THE ENVIRONMENT}

Exploitation of mineral raw materials consists of several technological phases, which for the ultimate goal have the extraction of mineral raw materials from the Earth's crust to be available for further processing.

Technological phases in the exploitation of mineral resources are:

- Drilling

- Blasting

- Loading

\footnotetext{
* Mining and Metallurgy Institute Bor

** This work is the result of the Project No. TR33021 "Research and Monitoring the Changes of the Stress Strain State in the Rock Mass "In-Situ" around the Underground Rooms with Development of Models with Special Reference to the Tunnel of the Krivelj River and Pit Bor" funded by the Ministry of Education, Science and Technological Development of the Republic of Serbia
} 
- Transport

- Disposal

- Crushing

- Processing of mineral raw materials

Regarding the potential impact on the environment, the development of mining activities has certain characteristics compared to other types of work/activities. Environmental and social impacts are diverse and sometimes last long after the completion of all mining activities. Therefore, the ecological impact of mining must be carefully assessed at an early stage of the mining project. The actions and resources needed to mitigate potential impacts have to be also evaluated after the completion of mining activities (Christmann et al., 2007).

Unlike the other industries, mining does not jeopardize the location of activities/ works, as there is no possibility to choose locations for formation the deposits of mineral raw materials. However, the mining company (Investor) can change the mining method by open pit mining with some method of underground mining in order to better preserve the natural resources in a given area, or even to minimize certain types of impact to the environment (ELAW, 2010).

The potential impacts of a certain technological phase in mining to the environment depend on a wide range of local factors such as the nature of ore and rock mass, geological and geotechnical parameters, extraction methods, generated and natural waste (solid, liquids or gases) and nature and vulnerability of local components of the environment.

\section{BLASTING}

In blasting, i.e. detonation of explosives and explosive mixtures results in a rapid change of state the unstable chemical components of explosives and transition to more stable detonation oxides, which occur in all three aggregate states, mostly in the form of gases and dust. The type of detonation product that will appear depends on:

- characteristics of explosives, that is, the chemical composition of components from which the explosive is made

- method of patronizing the explosive and chemical composition of packaging materials

- method of initiation and flow the chemical reaction of explosive decomposition that depends on the initiation impulse, rock hardness, blasting techniques, age of explosives, rock temperature, humidity, etc.

- chemical composition of rocks that are blasted and percentage content of matter in them that can enter into the chemical reaction with explosives during blasting, or appear as a product of rock destruction.

The quantity of gases produced during blasting at the open pits is about $1000 \mathrm{dm}^{3} / \mathrm{kg}$ of explosives. In gaseous mining products, the toxic gases are also encountered, such as: carbon monoxide, sulfur dioxide, nitrogen oxides, sulfur dioxide, and others depending on the blasting conditions.

In the case of mass-blasting at the open pit, a cloud of gas and dust is formed, windborne polluting the wider environment of the open pit, or in inversion of the atmosphere of the open pit endangers work of workers on the site at the open pit. When detonating explosives, a part of gases reaches the atmosphere (about 50\%), the second part (about 20\%) is absorbed by the blasting mass, and the third (about 30\%) fills the pores, cracks and empty spaces in the rock mass, from which it stands out during loading and contaminates the working environment at the open pit. 


\section{VOLUME OF A CLOUD OF GASES AND DUST FORMED AFTER BLASTING}

Volume of a cloud of gases and dust formed after blasting at the open pits can be determined on the basis of theoretical and empirical formulas (M. Miljković et al., 1998). The volume of a cloud composed of toxic and congested gases of blasting products is increased due to the temperature of explosive detonation $\mathrm{T}$, and amounts (M. Miljković et al., 1998):

$$
\mathrm{V}_{\mathrm{t}}=\mathrm{b} \frac{273+\mathrm{T}}{273} \mathrm{~A}, \mathrm{dm}^{3}
$$

where:

- A - amount of explosives used for blasting in the minefield of the open pit $(\mathrm{kg})$,

- b - amount of gases released in detonation one kilogram of explosive, Table $1\left(\mathrm{dm}^{3}\right)$,

- $\mathrm{T}$ - temperature of gaseous products after blasting. It is initially very high (about $1000^{\circ} \mathrm{C}$ ) and then rapidly decreases to the ambient air tempe-rature.

Table 1 Amounts of gases realized in detonation of $1 \mathrm{~kg}$ of explosives

\begin{tabular}{|l|c|c|c|c|c|}
\hline \multirow{2}{*}{ Type of explosive } & \multicolumn{3}{|c|}{ Amounts of $\mathbf{V}_{\text {ig }}, \mathbf{d m}^{\mathbf{3}} / \mathbf{k g}$ and \% and toxic gases } \\
\cline { 2 - 6 } & \multirow{2}{*}{ Total } & \multicolumn{2}{|c|}{$\mathbf{C O}$} & \multicolumn{2}{c|}{ NO $_{\mathbf{2}}$} \\
\cline { 3 - 6 } & & $\mathbf{d m}^{\mathbf{3}} / \mathbf{k g}$ & $\%$ & $\mathbf{d m}^{\mathbf{3}} / \mathbf{k g}$ & $\%$ \\
\hline Amonex-1 & 963 & 21.30 & 2.20 & 2.30 & 0.24 \\
\hline AN-FO mixture & 890 & 11.00 & 1.20 & 1.80 & 0.20 \\
\hline Majdanit 10 & 980 & 20.00 & 2.00 & 3.10 & 0.31 \\
\hline Average & 994 & 17.40 & 1.80 & 2.40 & 0.25 \\
\hline
\end{tabular}

\subsection{Blasting Parameters at}

\section{the Open Pit Veliki Krivelj in Bor}

Dusty-gas cloud in blasting occurs in three phases as follows:

- outbreaking or ejection from the borehole,

- loosening, crushing, demolishing, initiating and moving of massif, and finally throwing and falling of blasted mass, and

- under the influence of air strikes and seismic earthquakes.
The mass blasting method is applied at the open pit Veliki Krivelj. The average consumption of explosive amount per borehole in a series for AN-FO explosive is $504 \mathrm{~kg}$.

The cloud volume is composed of toxic and congested gases of blasting products and dusts increased for temperature of explosion detonation $\mathrm{T}$, and calculated for the following blasting series:

\footnotetext{
"Supplementary Mining Design for Excavation and Processing of Copper Ore in the deposit "Veliki Krivelj" for a capacity of $10.6 \times 10^{6}$ tons of wet ore - Technical Design for Mining, MMI Bor, 2011.
} 
- $\mathrm{V}_{\mathrm{t}}=1930615.38 \mathrm{dm}^{3}$

(for a series of blasting of $2100 \mathrm{~kg}$ of explosive)

- $\mathrm{V}_{\mathrm{t}}=4596703.29 \mathrm{dm}^{3}$

(for a series of blasting of $5000 \mathrm{~kg}$ of explosive),

- $\mathrm{V}_{\mathrm{t}}=45967032.96 \mathrm{dm}^{3}$

(for a series of blasting of $50000 \mathrm{~kg}$ of explosive),

The amount of toxic gases in the form of gaseous products of blasting depends upon the specific formation of toxic gases by detonation the certain types of explosive $\left(\mathrm{dm}^{3} / \mathrm{kg}\right)$, Table 1 , and it is determined on the basis of formula (M. Miljković et al, 1998):

$$
\mathrm{Q}_{\mathrm{ig}}=\frac{\mathrm{A} \cdot \mathrm{V}_{\mathrm{ig}}}{1000}, \mathrm{~m}^{3}
$$

where:

- A - amount of explosives used for blasting in the minefield of the open pit $(\mathrm{kg})$,

- $\mathrm{V}_{\mathrm{ig}}$ - amount of gases released in detonation one kilogram of explosive, Table $1\left(\mathrm{dm}^{3}\right)$,

The initial amount of a certain toxic gas in the form of gaseous blasting products is:

$$
\begin{aligned}
& \text { - } \mathrm{Q}_{\mathrm{ig}}=1869 \mathrm{~m}^{3} \\
& \text { (for a series of blasting of } 2100 \mathrm{~kg} \text { of } \\
& \text { explosive) } \\
& \text { - } \mathrm{Q}_{\mathrm{ig}}=4450 \mathrm{~m}^{3}
\end{aligned}
$$

(for a series of blasting of $5000 \mathrm{~kg}$ of explosive),

- $\mathrm{Q}_{\text {ig }}=44500 \mathrm{~m}^{3}$

(for a series of blasting of $50000 \mathrm{~kg}$ of explosive).

Concentration of $\mathrm{i}$-th gas in volumetric percentages in the cloud of gaseous blasting products amounts to (M. Miljković et al., 1998):

$$
\begin{aligned}
& \mathrm{C}_{\mathrm{ig}}=\frac{100 \cdot \mathrm{A} \cdot \mathrm{V}_{\mathrm{ig}}}{\mathrm{V}_{\mathrm{t}}}, \mathrm{m}^{3} \\
& \mathrm{C}_{\mathrm{ig}}=78 \%
\end{aligned}
$$

Table 1 gives data on formation the certain toxic gases for explosives used for blasting at the open pit.

The resulting cloud after blasting and decomposition of explosives, besides the gaseous products, also contains a large amount of dust. The total amount of dust that rises with the cloud of gaseous products after detonation of explosives according to the forecast is (M.Miljković et al., 1998):

$$
\mathrm{I}=\frac{0.149 \cdot \mathrm{a}^{2} \cdot \mathrm{V}_{\mathrm{b}}}{\mathrm{t}}, \mathrm{kg} / \mathrm{s}
$$

where:

- I - total amount of dust that rises with the cloud of gaseous products after detonation of explosives is a dust emission within a time interval of 10 to 40 seconds,

- a - specific consumption of explosives $\left(\mathrm{kg} / \mathrm{m}^{3}\right)$ of blasted rock mass $\mathrm{a}=\mathrm{A} / \mathrm{V}_{\mathrm{b}}$,

- $\mathrm{V}_{\mathrm{b}}$ - volume of a block on a level that is blasted.

$\mathrm{I}=186.98 \mathrm{~kg} / \mathrm{s}$

The direction, range and concentration of air pollution in the environment due to the occurrence of dust cloud depend on the ground configuration and air flow. If it is blasted when the southeast wind blows, the blasting pollution has a direction of moving towards the village Veliki Krivelj (very rarely). If the wind is from the northwest direction, the blasting pollution is directed towards the flotation tailing dump Veliki Krivelj.

\section{CONCLUSION}

On the basis of presented amounts of gases and dust in blasting at the open pit Veliki Krivelj, the gaseous blasting products 
and raised dust threaten the environment by dangerous concentrations of gases and harmful dust. On the basis of this, it can be established that a direct impact on the environment due to the wind rose has on the surrounding village of Veliki Krivelj. In order to deal with it, it is necessary to take the appropriate protection measures as early as possible in order to eliminate the subsequent negative effects.

\section{REFERENCES}

[1] Kogel J.E., Trivedi N.C., Barker J. M., Krukowski S. T., Industrial Minerals Rocks: Commodities, Markets, and Uses, Seventh Ed. SME-Society for Mining, Metallurgy and Exploration, 2006, ISBN 978-0-8733523-38.

[2] Jorge Castilla-Gómez, Juan HerreraHerbert, Environmental Analysis of Mining Operations: Dynamic Tools for Impact Assessment - Minerals Engineering 76 (2015) 87-96, 2015

[3] Christmann P., Arvanitidis N., Martins L., Recoché G., Solar S., Towards the Sustainable Use of Mineral Resources: A European Geological Surveys Perspective. Miner. Energy - Raw Mater. Rep. 22 (3-4), 2007, 88-104.

[4] Environmental Law Alliance Worldwide ELAW, 2010. Guidebook for Evaluating Mining Project EIAs, Eugene, OR 97403 USA. ISBN: 9780-9821214-36.

[5] M. Miljković, Z. Stojković, The Impactof the Open Pit Mining of Metal Ore on the Ecological Factors of the Environment, Monography, Bor 1998. (in Serbian)

[6] T. Apostolovski Trujić, M. Mikić, V. Tasić, Air Quality Control in the Area of Environmental Influence, The $46^{\text {th }}$
International October Conference on Mining and Metallurgy-Proceedings, Serbia, 2014, 545-549.

[7] M. Mikić, D. Kržanović, R. Rajković. Effect of Exploitation at Social Community, and Other Public Facilities in Zone of Open Pit Južni Revir in Majdanpek, Mining 2012, Privredna Komora Srbije, 397-402.

[8] M. Mikić, R. Rajković, D. Kržanović. Recultivation of Degraded Area at the Open Pit Južni Revir in Majdanpek, Mining 2012, Privredna Komora Srbije, 491-499 (in Serbian)

[9] R. Rajković, M. Bugarin, V. Marinković: Stability Analysis of the Tailing Dump "Oštreljski planir" of the Open Pit "Bor" in a Function of Drainage, Mining and Metallurgy Engineering Bor, 3/2013, pp. 57-64 (in Serbian)

[10] M. Ignjatović, S. Ignjatović, M. Negovanović, R. Rajković, L. Djurdjevac Ignjatović, D. Ignjatović: Determination of the Final Slope Angle of the Open Pit Mine During Exploitation of Oil Shale from Aleksinac Deposit During GeoStudio2007 - SLOPE/W Program; TTEM - Technics Technoogies Education Management 2011/3; pp. $615-621$.

[11] M. Ignjatović, R. Rajković, B. Rajković, D. Milanović, M. Popović: Stability Analysis off Open Pit "Progorelica" by the Bishop Method and Program Plan Failure Analysis; II International Symposium "Mining 2011" Mining Presents State and Future Prospects and Sustainable Development; Vrnjačka banja 10 - 13 May 2011; pp. 599 - 603.

[12] R. Lekovski, M. Mikić, D. Kržanović; The Impact of the Flotation Tailing Dumps on the Environment of Bor and 
Protective Measures; Mining and Metallurgy Engineering Bor, 2/2013, pp. 107-116

[13] M. Mikić, D. Kržanović, M. Jovanović, M. Maksimović: Review of the
Open Mine South Mining District Majdanpek Impact on the Environment and Protective Measures, Mining and Metallurgy Engineering Bor 3/2015, pp. 1-16 